University of Nebraska - Lincoln

DigitalCommons@University of Nebraska - Lincoln

Faculty Publications from the Harold W. Manter Laboratory of Parasitology

10-1976

\title{
Fabespora vermicola sp. n., the First Myxosporidan from a Platyhelminth
}

Robin M. Overstreet

Gulf Coast Research Laboratory, robin.overstreet@usm.edu

Follow this and additional works at: https://digitalcommons.unl.edu/parasitologyfacpubs

Part of the Parasitology Commons

Overstreet, Robin M., "Fabespora vermicola sp. n., the First Myxosporidan from a Platyhelminth" (1976). Faculty Publications from the Harold W. Manter Laboratory of Parasitology. 304.

https://digitalcommons.unl.edu/parasitologyfacpubs/304

This Article is brought to you for free and open access by the Parasitology, Harold W. Manter Laboratory of at DigitalCommons@University of Nebraska - Lincoln. It has been accepted for inclusion in Faculty Publications from the Harold W. Manter Laboratory of Parasitology by an authorized administrator of DigitalCommons@University of Nebraska - Lincoln. 


\title{
FABESPORA VERMICOLA SP. N., THE FIRST MYXOSPORIDAN FROM A PLATYHELMINTH*
}

\author{
Robin M. Overstreet \\ Gulf Coast Research Laboratory, Ocean Springs, Mississippi 39564
}

ABstract: The myxosporidan Fabespora vermicola sp. n., tentatively placed in the family Myxidiidae, is described from the digenean Crassicutis archosargi in an estuarine fish. The myxosporidan becomes the first known from a platyhelminth and the third from an invertebrate. It differs from the only other member of the genus primarily by having polar filaments 32 to $44 \mu \mathrm{m}$ long rather than about $8 \mu \mathrm{m}$, and an infection with it can stop reproduction in the digenean host either by physical means or by necrosis of gametes.

While examining a digenean from an estuarine fish, I noticed a myxosporidan conspicuous in its tegument and less apparent in other tissues (Overstreet, 1976). Heavy infections by the myxosporidan resulted in ceased production of viable eggs and other pathological alterations in the worm. The first myxosporidan known from platyhelminths and the third infecting invertebrates, it belongs to a genus also infecting fish. Kudo (1920) listed the others as Myxobolus sp. from an annelid and Chloromyxum diploxys (Gurley 1893) Thélohan 1895 from an insect. A few Myxosporida, primarily a piscine-infecting group, do parasitize other cold-blooded vertebrates, amphibians and reptiles, whereas the related actinomyxidans infect invertebrates.

\section{MATERIALS AND METHODS}

Material was examined fresh, smeared and then stained with Giemsa's solution, fixed and then cleared in lactic acid, and sectioned; it was measured using a measuring eyepiece or a Watson image-shearing eyepiece. I drew illustrations with the aid of a camera lucida.

\section{DESCRIPTION \\ Fabespora vermicola sp. $n$. (Figs. 1-9, 11)}

Developing stages: Histozoic. Trophozoite nearly spherical in living state, up to $13 \mu \mathrm{m}$ in diameter; it and later stages most numerous sur-

Received for publication 31 October 1975.

* This study was conducted in cooperation with the U. S. Department of Commerce, NOAA, National Marine Fisheries Service, under PL 88309, Project No. 2-262-R and NOAA, Office of Sea Grant, under Grant No. 04-6-158-44060. The U. S. Government is authorized to produce and distribute reprints for governmental purposes notwithstanding any copyright notation that may appear hereon. rounding host's reproductive organs, but also among any parenchymal cells. Pansporoblast containing 2 sporoblasts, each producing 1 spore. Immature spore binucleate.

Spore: Mature pairs in tegument of host. Wall ellipsoidal in shape. Sutural line inconspicuously ridged. Valves lacking evident sculpturing; one valve overlapping that of other for short distance. Sutural line of valves perpendicular to long axis of spore near its equator. Polar capsules 2, 1 at each end of spore; filaments extruding terminally from capsules, foramina slightly offcenter but on same side of longitudinal axis. Sporoplasm lacking iodinophilous vacuole, that of mature spore within host occasionally with fused nuclei or at least appearing so. Dimensions of fresh material and that fixed by several methods presented in Table I. Thickness same as width since shape ellipsoidal.

Type host: Crassicutis archosargi Sparks and Thatcher 1960 (Homalometrinae) in Archosargus probatocephalus (Walbaum), sheepshead (Sparidae).

Sites: Among parenchymal cells, surrounding reproductive organs, and in integument of digenean.

Locality: Lower portion of Escatawpa River, Jackson County, Mississippi.

Syntypes deposited: USNM Helm. Coll. No. 74137 ( 2 whole mounts of infected hosts). No. 74138 ( 2 slides with sections).

Nomenclature: The Latin specific name vermicola is derived from "vermis," meaning worm and the feminine suffix "-cola," meaning inhabiting.

\section{OBSERVATIONS}

Early sporogony of $F$. vermicola occurred among parenchymal cells where nearly mature spores also develop; however, early stages located most densely around the ovary and other reproductive organs (Figs. 3-6).

The most mature spores, still disporous and surrounded by a membrane, resided in the tegument (Fig. 8). While in the tegument, many spores clearly possessed binucleated sporoplasms. Others, however, appeared to have a single large nucleus. Whether fusion had oc- 

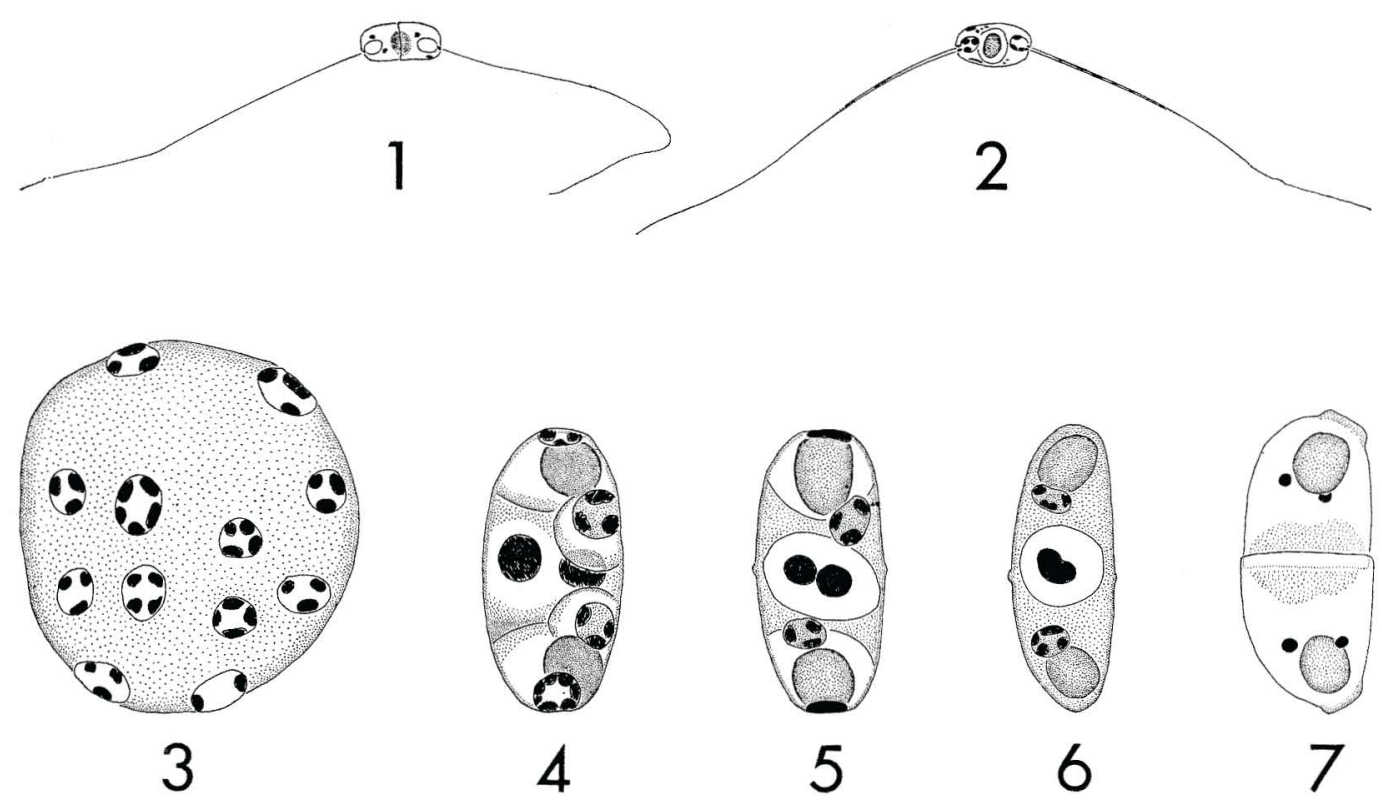

Figures 1-7. Fabespora vermicola. 1. Living spore, unstained. 2. Spore stained with Giemsa's solution after smeared specimen had dried, spore $7.5 \mu \mathrm{m}$ long, longest polar filament $36 \mu \mathrm{m}$ long. (Note width of dried polar filament.) 3-6. Developing stages, Harris' hematoxylin and eosin. 7. Living spore, unstained.

curred or whether all undergo it upon maturity remains unestablished. Also, whether these spores migrate to and through the tegument also awaits clarification. Possibly, replacement of host tissues results in outward passive trans- port of the spores. Sloughing of the tegument could release spores, but by examining trematodes under minimal coverslip pressure, I saw paired spores moving through the tegument to the external medium.

TABLE I. Dimensions in micrometers of mature ${ }^{\mathrm{a}}$ fresh and fixed spores of Fabespora vermicola.

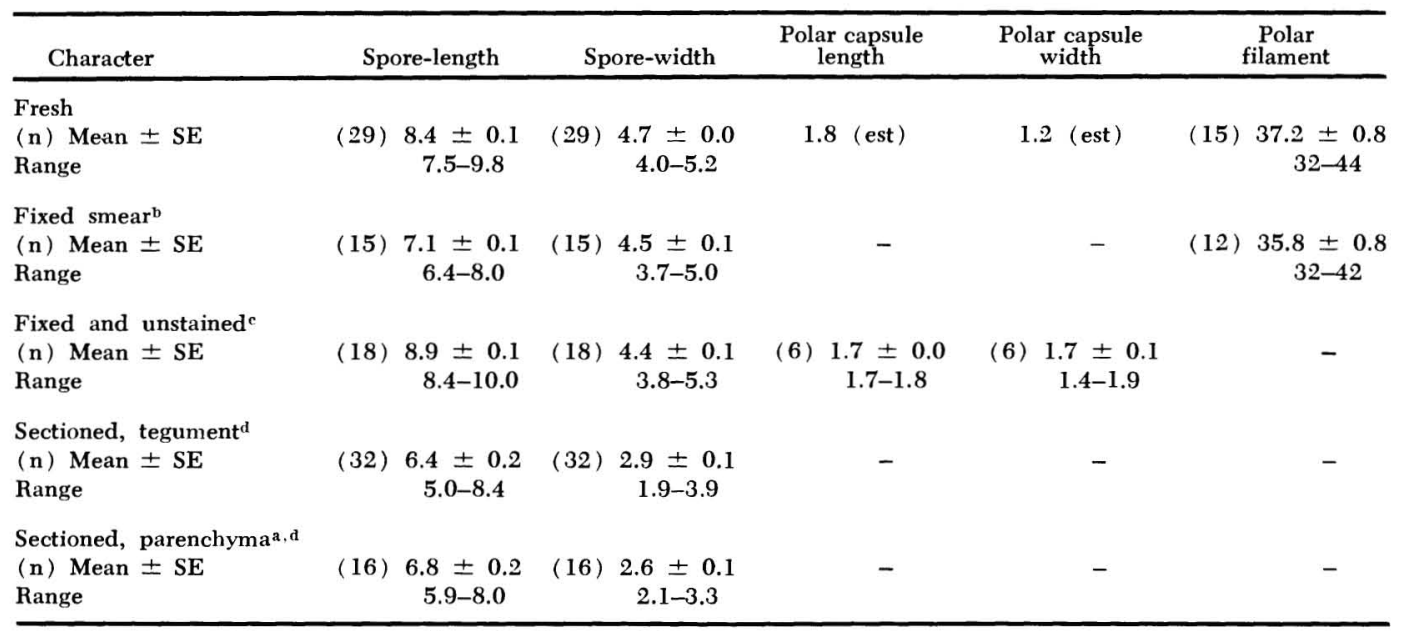

a Sectioned material among parenchymal cells not fully mature.

b Material fixed, stained in Giemsa's, and mounted in Permount.

e Material fixed in AFA, transferred to $70 \%$ ethanol, and cleared in lactic acid.

d Only complete spores measured from sectioned material. 


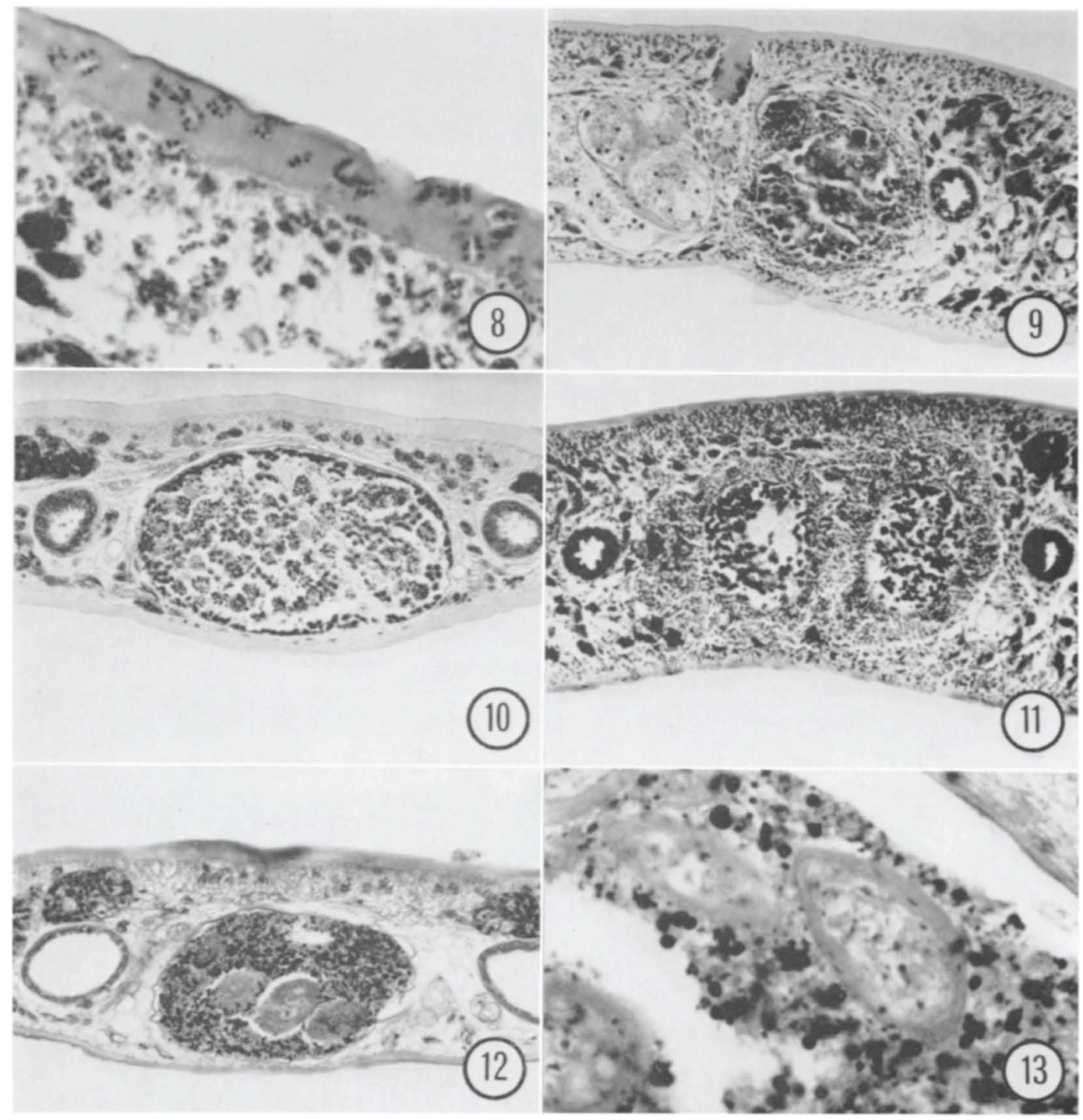

Figures 8-13. Crassicutis archosargi. 8. Disporoblastic pansporoblasts with mature spores of Fabespora vermicola in the tegument and developing ones in the parenchyma, Harris' hematoxylin and eosin, $\times$ 559. 9. Degenerating ova in lighter infection than shown in Fig. 8. Note developing stages around ovary, Harris' hematoxylin and eosin, $\times$ 148. 10. Cross section through testis of noninfected individual, Harris' hematoxylin and eosin, $\times 161$. 11. Cross section through posterior lobed portion of testis of infected individual. Note dense layer of developing spores around testis and among densely infected parenchyma dorsal and ventral to testis, Heidenhain's iron hematoxylin, $\times 153$. 12. Cross section of necrotic testis with cysts, specimen not infected by Fabespora vermicola, Heidenhain's iron hematoxylin, $\times$ 152. 13. Close up of different section from same specimen as used for Fig. 12 showing some necrotic gametocytes and cysts, $\times 596$.

In one instance, I observed under high magnification a single released spore actively moving at a relatively moderate speed. The spore appeared to undulate for periods of up to several minutes, followed by intermittent pauses before continuation of the locomotary behavior. Such behavior has not been reported previously for myxosporidans.

Measurements of spores listed in Table I portray some expected differences. The fixed spores in smears and sections average smaller than fresh material. Those cleared in lactic 
acid, however, were longer, but narrower, than the fresh spores. Regardless of the state of fixation, considerable variation existed in the size among specimens from both the same and different hosts.

From 71 sheepshead 45 to $425 \mathrm{~mm}$ in standard length from various Mississippi estuaries, only 14,118 to $277 \mathrm{~mm}$ long, harbored the worm. The most heavily infected fish had 120 worms. Even though some worms occurred in fish near Ocean Springs, only those in 3 of 11 from the lower Escatawpa River near its junction with the Pascagoula River possessed flukes with various stages of $F$. vermicola. The infection was first apparent on 2 November 1970, then on 20 January 1971, and not again despite several collecting trips until 15 November 1974.

Infections affect egg-production. Of 34 worms examined from fish caught 20 January 1971 , nine contained mature spores present in the tegument. Only one of those possessed any eggs; it had one egg and was relatively lightly parasitized. All the worms without spores in the tegument produced numerous eggs, although some of these had early stages of infections. In 1974, observed infections had progressed less and most worms produced eggs. In individuals with heavy infections, reproductive ducts often appeared obstructed and organs such as Mehlis' gland destroyed, but the parasite rarely, if ever, occupied gonadal tissue. Still, however, when developing parasites encircled the ovary (Fig. 9) and testes (Fig. 11), the gametocytes degenerated. Necrotic gonads were common. In any event, the myxosporidan acts as a biological control agent.

Two worms without any sign of the myxosporidan, but found in the same host as infected individuals, also had necrotic testes. In these, elliptical bodies occurred in the testes (Figs. 12, 13). Those bodies consisted of concentric laminations towards the periphery which, when stained with Heidenhain's iron hematoxylin, did not take up hematoxylin and of degeneration in the central portion with necrotic debris, not too unlike that seen elsewhere in the diseased testis.

\section{DISCUSSION}

Fabespora vermicola differs from $F$. nana Naidenova and Zaika 1969, the only other described species of Fabespora Naidenova and Zaika 1969, primarily by having a considerably longer polar filament, 32 to $44 \mu \mathrm{m}$ rather than $8 \mu \mathrm{m}$ or less. The sutural ridge apparently protrudes less in $F$. vermicola, and the kind of and site in the host differs. Developing stages of $F$. nana lack description.

Naidenova and Zaika (1969) did not observe the sutural line in $F$. nana despite many attempts. They concluded that the line probably coincided with the ridge, suggesting the species be separated into the new family Fabesporidae of the Eurysporea. Because they found no trace of a longitudinal sutural line and they found anomalous spores having three polar capsules and triradiating ridges, anomalies they consider common in eurysporeans, they discounted any affinity between their species and the myxidiids.

In contrast and considering the assumed importance of the polar capsules occupying the ends of the ellipsoidal spore, I believe Fabespora belongs in the Myxidiidae. That placement is tentative, especially since the foramina of the polar capsules in both species have not reached a completely bipolar position. Assuming further studies show that placement as correct, the sutural line being perpendicular to the long axis culminates an evolutionary transition in elongated spores from parallel to perpendicular. Myxidium Bütschli contains members typically with straight lines coinciding with or at an acute angle to the axis, and Zschokkella Auerbach has members with sinuous lines. Species of Sphaeromyxa Thélohan have either straight or arcuate spores with either straight or sinuous sutural lines. Characterized by having members with truncated ends, Sphaeromyxa is considered the most primitive myxidiid by some (Shulman, 1966).

Because of the perpendicular sutural line in the equatorial region, the presence of one species in an invertebrate, and the apparent paucity of species, I consider Fabespora, and especially $F$. vermicola, advanced. This species probably evolved from a piscine-inhabiting ancestor. Numerous attempts to find a myxosporidan in the sheepshead proved unsuccessful, but a third species with some similar characteristics will be described soon from another fish by Charles Johnson of Duke Marine Laboratory (pers. comm.). 


\section{ACKNOWLEDGMENTS}

I thank Dr. Paul A. Meglitsch of Drake University for reading my first draft and commenting on Fabespora and Edward C. Whatley, Jr. of the Gulf Coast Research Laboratory for providing technical assistance.

\section{LITERATURE CITED}

Kudo, R. 1920. Studies on Myxosporidia. A synopsis of genera and species of Myxosporidia. Ill Biol Monogr 5: 3-265.
Naidenova, N. N., ANd W. E. Zatka. 1969. Two new species of Protozoa from the fishes of the Black Sea. Parazitologiya 3: 97-101. (In Russian)

Overstreet, R. M. 1976. A redescription of Crassicutis archosargi, a digenean exhibiting an unusual tegumental attachment. J Parasitol 62: 702-708.

Shulman, S. S. 1966. Myxosporidia in the Fauna of U.S.S.R. Academia Nauk U.S.S.R. Nauka, Moscow and Leningrad, 507 p. (In Russian) 